Research Article

\title{
Comparative study of problem based learning versus structured group discussion in teaching pharmacology
}

\author{
Laveesh M. R., Vishwaprakash M. K.*, Somashekara S. C.
}

\begin{abstract}
Department of Pharmacology, Malabar Medical College and Research Institute, Modakkallur673315, Kozhikode, Kerala, India

Received: 30 July 2016

Accepted: 03 August 2016

*Correspondence to:

Dr. Vishwaprakash MK,

Email: vishwapujar79@ gmail.com

Copyright: (C) the author(s), publisher and licensee Medip Academy. This is an openaccess article distributed under the terms of the Creative Commons Attribution NonCommercial License, which permits unrestricted noncommercial use, distribution, and reproduction in any medium, provided the original work is properly cited.
\end{abstract}

\begin{abstract}
Background: Pharmacology for undergraduate students is taught primarily with a drug centric approach using didactic lectures. Hence the students can't correlate the drug with the disease and loses interest in the subject. Problem based learning (PBL) on the other hand involves effort from the students themselves which gives them a sense of ownership and helps to enhance their analytical skills. Structured group discussion (SGD) is used to enable students' directed learning where they are given structured objectives on the topic followed by a discussion.

Methods: This was a quasi-experimental study done on 100 second year MBBS students. They were divided into 2 groups (group A and B) of 50 each. Group A was allotted a therapeutic problem (PBL) and the group B was assigned structured objectives on the same topic (SGD). Later the groups were switched for PBL and SGD and given another topic. A pre and post-test was conducted using MCQs for each session. Finally a feedback was taken from all the students.

Results: There was a statistically significant gain in knowledge following both the methods of learning. However there was no statistically significant difference in the mean marks between PBL and SGD. Nonetheless the mean for PBL (5.42) in group A and B was greater than that of SGD (5.17) in the same. Students' feedback was also better for PBL under all the heads.

Conclusions: PBL and SGD are effective small group methods for teaching undergraduate medical students. However learning outcome with PBL is better than SGD.
\end{abstract}

Keywords: Structured group discussion, Problem based learning

\section{INTRODUCTION}

Medical curriculum is primarily intended to meet three goals: the student must acquire a body of basic biomedical knowledge, the student must learn to apply this basic knowledge in patient care and should acquire the attitude, habits and techniques of a lifelong learner. ${ }^{1}$ Unfortunately, the traditional method of teaching in medical education is unable to impart these skills to the medical student. Moreover the information overload and monotony of the traditional curriculum makes the learning process an arduous task for the students. Small group instructional methods like problem based learning (PBL) and structured group discussion (SGD) can help to break the monotony and assist the students in selfdirected learning. Problem-based learning (PBL) is a student centred pedagogy in which students learn about a particular subject through the experience of related problem solving exercise. The students acquire the domain knowledge along with the critical ability to analyse the problem.

The concept of problem based learning was developed at the McMaster University Medical School in Canada in the $1960 \mathrm{~s}^{2-4}$ In this instructional method students are divided into small groups of 8-10 each. One of the limitations with PBL is the need for greater resources. This is a major concern in today's times where there is ever increasing number of medical students and a dearth of skilled medical faculty. In a SGD, structured objectives are given to the students. They come prepared with the topic and a group discussion is done in which the 
faculty merely acts as a facilitator. Discussion among the students is encouraged. ${ }^{5}$

As both the methods are in vogue, I have selected this study to compare their learning outcomes for devising a teaching strategy in undergraduate students of pharmacology. Aims and objectives of the study was to compare the performance of students with PBL and structured group discussion in pharmacology, to compare the pre and post test scores of PBL and SGD and to compare the student feedbacks of PBL and SGD.

\section{METHODS}

The study was conducted by the department of Pharmacology, Malabar Medical College, Kozhikode, India. The study period was done between November 2015 to February 2016. The study population was comprised of 100 second year MBBS students from Malabar Medical College.

A quasi experimental study was designed for the study. The research proposal was submitted to the Institutional Ethics Committee and the approval was obtained. Afterwards, 100 second year (fifth semester) MBBS students were selected for the study. They were further divided into group A and group B of 50 each by random sampling method. Group A was chosen for problem based learning and group B for structured group discussion on the same topic. A pretest was conducted using 25 multiple choice questions (MCQ).

Group A was further subdivided into 5 subgroups of 10 each and each of these subgroups were given a clinical problem on congestive heart failure. The students in group B were given structured objectives for the discussion on congestive heart failure. After two days, for the group A, the faculty briefly explained the problem which was followed by an interactive session with the students. For the group B, a structured group discussion was carried out followed by questions pertaining to the topic in which the faculty merely acted as a facilitator. A post test was conducted for both the groups using multiple choice questions. The answers were discussed and the result was announced the next day. A feedback was obtained from the students after both the sessions.

This was followed by switching groups for PBL and SGD. Group B was further subdivided into five subgroups of 10 each. The topic allotted for both the groups was hypertension. A pretest with MCQs was conducted. Group A was given structured objectives to be discussed for SGD and group B a therapeutic problem on Hypertension for PBL. Two days later the topic was dealt using PBL and SGD and a post test was done for both the groups using MCQ. A feedback form was also collected from the students after the sessions.

\section{Statistical analysis}

Statistical analysis of pre-test and post-test data was compared using paired ' $t$ ' test and unpaired ' $t$ ' test.

\section{RESULTS}

The mean of PBL (10.84) was greater than that of SGD (8.40) in group A (Table 1). Similarly in group B (Table 2), the mean of PBL (10.68) was greater than that of SGD (9.56).With the above results we can conclude that PBL was more effective than SGD in group B. When the pre and post-test marks were compared for PBL and SGD, it was found that the values were statistically significant $(\mathrm{P}$ value $<0.001)$ for both the instructional methods of teaching. Nonetheless, the mean pre-test as well as post-test marks were higher for PBL than SGD (Table 3). The difference in mean marks between PBL and SGD was not found to be statistically significant, $P$ value $>0.05$ (Table 4).

The students' feedback was positive for PBL in all the heads. In fact the overwhelming majority either strongly agreed or agreed to the usefulness of PBL in improving their academic outcomes (Table 5). The feedback was also positive for SGD as an instructional mode for small groups. However the response was relatively lesser for SGD when compared to that of PBL (Table 6).

Table 1: Intra group statistics for group A.

\begin{tabular}{|lll|l|}
\hline $\begin{array}{l}\text { Instructional } \\
\text { mode }\end{array}$ & Mean & $\begin{array}{l}\text { Std. } \\
\text { deviation }\end{array}$ & $\begin{array}{l}\text { Std. error } \\
\text { mean }\end{array}$ \\
\hline PBL & 10.8400 & 2.89518 & 0.40944 \\
\hline SGD & 8.4000 & 2.74048 & 0.38756 \\
\hline
\end{tabular}

Table 2: Intra group statistics for group $B$.

\begin{tabular}{|lll|l|}
\hline $\begin{array}{l}\text { Instructional } \\
\text { mode }\end{array}$ & Mean & $\begin{array}{l}\text { Std. } \\
\text { deviation }\end{array}$ & $\begin{array}{l}\text { Std. error } \\
\text { mean }\end{array}$ \\
\hline PBL & 10.6800 & 2.43646 & 0.34457 \\
\hline SGD & 9.5600 & 2.32256 & 0.32846 \\
\hline
\end{tabular}

Table 3: Comparison of pre and post-test marks.

\begin{tabular}{|c|c|c|c|c|c|}
\hline Intervention & Number & $\begin{array}{l}\text { Pretest mean marks } \\
\text { with SD }\end{array}$ & $\begin{array}{l}\text { Post-test mean marks with } \\
\text { SD }\end{array}$ & $\mathbf{t}$ value (paired $\mathbf{t}$ test) & P-value \\
\hline PBL & 100 & $5.42(2.15)$ & $10.76(2.66)$ & -36.63 & 0.000 \\
\hline SGD & 100 & $5.17(2.14)$ & $8.98(2.59)$ & -20.46 & 0.000 \\
\hline
\end{tabular}


Table 4: Comparison of difference in mean marks between PBL and SGD.

\begin{tabular}{|llllll|}
\hline Intervention & Number & Difference in mean marks & SD & t-value (unpaired 't' test) & P-value \\
\hline PBL & 100 & 0.16 & 2.66 & 0.299 & 0.149 \\
\hline SGD & 100 & -1.16 & 2.53 & 0.283 & 0.370 \\
\hline
\end{tabular}

Table 5: Students' feedback on PBL.

\begin{tabular}{|llllll|}
\hline Problem based learning (PBL) & $\begin{array}{l}\text { Strongly } \\
\text { agree }\end{array}$ & Agree & $\begin{array}{l}\text { No } \\
\text { opinion }\end{array}$ & $\begin{array}{c}\text { Disagree } \\
\text { Strongly } \\
\text { disagree }\end{array}$ \\
\hline PBL was more useful in understanding the topic & $23 \%$ & $29 \%$ & $32 \%$ & $10 \%$ & $6 \%$ \\
\hline I was motivated by PBL to learn further & $35 \%$ & $38 \%$ & $19 \%$ & $5 \%$ & $3 \%$ \\
\hline PBL has given a sense of ownership to my studies & $31 \%$ & $41 \%$ & $18 \%$ & $8 \%$ & $2 \%$ \\
\hline PBL helps to integrate my knowledge in pharmacology & $26 \%$ & $44 \%$ & $20 \%$ & $9 \%$ & $1 \%$ \\
\hline $\begin{array}{l}\text { Knowledge gained in PBL was useful in scoring more } \\
\text { marks in the examinations }\end{array}$ & $26 \%$ & $40 \%$ & $16 \%$ & $12 \%$ & $6 \%$ \\
\hline
\end{tabular}

Table 6: Students' feedback on SGD.

\begin{tabular}{|llllll|}
\hline Structured group discussion(SGD) & $\begin{array}{l}\text { Strongly } \\
\text { agree }\end{array}$ & Agree & $\begin{array}{l}\text { No } \\
\text { opinion }\end{array}$ & $\begin{array}{l}\text { Disagree } \\
\text { Dtrongly } \\
\text { disagree }\end{array}$ \\
\hline SGD was more useful in understanding the topic & $21 \%$ & $29 \%$ & $23 \%$ & $18 \%$ & $9 \%$ \\
\hline I was motivated by SGD to learn further & $27 \%$ & $31 \%$ & $19 \%$ & $18 \%$ & $5 \%$ \\
\hline SGD has given a sense of ownership to my studies & $18 \%$ & $26 \%$ & $29 \%$ & $23 \%$ & $4 \%$ \\
\hline SGD helps to integrate my knowledge in pharmacology & $15 \%$ & $23 \%$ & $32 \%$ & $22 \%$ & $8 \%$ \\
\hline $\begin{array}{l}\text { Knowledge gained in SGD was useful in scoring more } \\
\text { marks in the examinations }\end{array}$ & $14 \%$ & $23 \%$ & $30 \%$ & $23 \%$ & $10 \%$ \\
\hline
\end{tabular}

\section{DISCUSSION}

The study was conducted by the Department of Pharmacology, Malabar Medical College, Kozhikode, India from November 2015 to February 2016. The results showed that both the instructional methods show a positive correlation. There was statistically significant gain in knowledge following both methods of learning ( $\mathrm{p}$ value $<0.05$ ). The standard deviation for PBL was 2.89 and that of SGD was 2.74. The standard error of mean for PBL was 0.409 and that of SGD was 0.387 in group A.

In group B, the Standard deviation for PBL was 2.43 and that of SGD was 2.32.The Standard error of mean for PBL was 0.34 and that of SGD was 0.32 .

An overwhelming $66 \%$ of the students think that PBL has helped them to score good marks in the test which is felt by only $37 \%$ of the students in case of SGD. Similarly on all accounts students' feedback largely favors PBL as an instructional mode of teaching pharmacology in the undergraduate students. The above said results are not in concurrence with Meshram et al which concludes that SGD produces better learning outcome than PBL. ${ }^{6}$ However Jong et al and Lee et al strongly advocates for PBL. ${ }^{7,8}$ We think that the problem based approach aroused the inherent tendency to solve a puzzle in the undergraduates which possibly acted as a stimulus to get to the root of the problem and find the solution to it. This was not the case in SGD where the students had to get answers for the structured objectives given to them. With the above results we conclude that PBL is a better instructional method of teaching for a small group of students in pharmacology. However long term studies in a larger study group involving various batches of students could be helpful in establishing the above findings.

\section{CONCLUSION}

Problem based learning and structured group discussion are effective small group methods for teaching undergraduate medical students. However learning outcome with PBL is better than SGD. Both PBL and SGD requires larger resources. However if faculty are trained, these could be used regularly for better learning outcomes.

\section{ACKNOWLEDGEMENT}

The authors would like to thank all the second MBBS students of 2013 batch for their participation in the study. I would be grateful to my head of the department for the guidance and technical support to conduct the study.

Funding: No funding sources

Conflict of interest: None declared

Ethical approval: The study was approved by the Institutional Ethics Committee 


\section{REFERENCES}

1. Donner RS, Bickley H. Problem based learning in American medical education: an overview. Bull Med Libr Assoc.1993;81(3):294-8.

2. Silver H, Cindy E. Problem based learning: what and How do students learn? Educational Psychology Review. 2004;16(3):235.

3. Colliver J. Effectiveness of problem-based learning curricula. Research and theory Academic Medicine. 2000;75(3):259-66.

4. Neville AJ, Norman GR. PBL in the undergraduate MD program at Mcmaster university: Three iterations in three decades. Academic Medicine. 2007;82(4):370-37.
5. Raut S, Shreechakradhar M, More SR, Rathod VS. Developing competencies of medical students using group discussion as TL method. J Dental Med. 2014;13(1):24-7.

6. Meshram AW, Meshram AK, Waghmare T. Structured group discussion versus problem based learning a comparison in medical education. Int $\mathbf{J}$ Biomed Adv Res. 2015;6(12):839-43.

7. Jong Z. Interactive seminars or small group tutorials in preclinical medical education: results of a randomized controlled trial. British Med C. 2010;10(79):2-9.

8. Lee R, Kwan YC. The use of problem based learning in medical education. J Med Education. 1997;1(2):149.

Cite this article as: Laveesh MR, Vishwaprakash MK, Somashekara SC. Comparative study of problem based learning versus structured group discussion in teaching pharmacology. Int J Basic Clin Pharmacol 2016;5:1877-80. 